\title{
BMJ Open Application of a novel sex independent anthropometric index, termed angle index, in relation to type 2 diabetes: a Trinidadian case-control study
}

\author{
Terry Gavaskar Ramnanansingh, ${ }^{1}$ Shivananda Bijoor Nayak ${ }^{2}$
}

To cite: Ramnanansingh TG, Nayak SB. Application of a novel sex independent anthropometric index, termed angle index, in relation to type 2 diabetes: a Trinidadian case-control study. BMJ Open 2019;9:e024029. doi:10.1136/ bmjopen-2018-024029

- Prepublication history and additional material for this paper are available online. To view these files, please visit the journal online (http://dx.doi org/10.1136/bmjopen-2018024029).

Received 19 May 2018 Revised 15 November 2018 Accepted 28 November 2018

Check for updates

(c) Author(s) (or their employer(s)) 2019. Re-use permitted under CC BY-NC. No commercial re-use. See rights and permissions. Published by BMJ.

${ }^{1}$ School of Pharmacy, Faculty of Medical Sciences, The University of the West Indies, St Augustine, Trinidad and Tobago

${ }^{2}$ Biochemistry Unit, Department of Preclinical Sciences, Faculty of Medical Sciences, The

University of the West Indies, St Augustine, Trinidad and Tobago

Correspondence to Professor Shivananda Bijoor Nayak; shiv25@gmail.com

\section{ABSTRACT}

Objective To develop a novel sex independent anthropometric index, termed as angle index, related to type 2 diabetes.

Design Case-control.

Participants The study comprised 121 participants and were divided into two groups. One group had no form of diabetes and served as controls $(n=50)$. The other group had the condition of type 2 diabetes $(n=71) .31 \%(n=37)$ of the subjects were male and $69 \%(n=84)$ were female. $62 \%(n=75)$ of the subjects were of East Indian ethnicity, $28 \%(n=34)$ were of African ethnicity and $10 \%(n=12)$ were of mixed ethnicity.

Setting Participants of the study were from the island of Trinidad, located in the Caribbean. Patients in the study were selected at random from hospital records.

Primary outcome measure It was hypothesised that the mean angle index of patients with type 2 diabetes would be higher than the mean angle index of patients without type 2 diabetes.

Results Patients with type 2 diabetes had a significantly higher angle index value as compared with controls $(p<0.001)$. Angle index was the superior sex independent anthropometric index in relation to type 2 diabetes (area under the curve $=0.72 ; p<0.001$ ) as compared with other sex independent variables. Angle index correlated with glycated haemoglobin $\left(r_{s}=0.28, p=0.003\right)$ and fasting blood glucose $\left(r_{s}=0.31, p=0.001\right)$ levels. Patients with type 2 diabetes were four times more likely to have an angle index greater than $184^{\circ}$ (OR $4.2,95 \% \mathrm{Cl} 1.8$ to 9.9 ) as compared with controls.

Conclusion Angle index was a superior sex independent index for discriminating between patients with and without type 2 diabetes, as compared with waist circumference, abdominal volume index, conicity index, blood pressure readings, triglyceride levels and very low-density lipoprotein levels.

\section{INTRODUCTION}

There is currently no known simple predictor for type 2 diabetes; however, one of the most useful sex independent diagnostic parameters for type 2 diabetes is a glycated haemoglobin (HbA1c) reading of $\geq 6.5 \%$ $(\geq 48 \mathrm{mmol} / \mathrm{mol}) .{ }^{1-3}$ This study was motivated

\section{Strengths and limitations of this study}

- The sample size was sufficient to conclusively demonstrate that angle index was higher in patients with type 2 diabetes as compared with patients without the condition.

- The study demonstrates the importance of characterising central obesity geometrically.

- Although angle index was independent of sex, it was more complicated to calculate by hand as compared with other anthropometric indices.

- Angle index was a good discriminator for patients with and without type 2 diabetes, but due to the case-control design of the study it remains to be seen whether a prospective study will demonstrate that angle index is a good predictor for type 2 diabetes.

in a similar fashion to provide a sex independent anthropometric index that could serve as a predictor or possible diagnostic criteria for type 2 diabetes. This novel anthropometric index could have the possibility of being related to hypertension, cardiovascular disease and even physical attractiveness. ${ }^{4-7}$

Euclidean geometry was applied to derive a possible novel anthropometric index. The geometrical approach led to a derivation of a trigonometric relationship among minimal waist, umbilical waist and hip circumferences. The geometrical approach does not have to be limited to trigonometry, but other aspects of geometry can be applied as demonstrated with a previous study. ${ }^{8}$ For the purposes of this study, the possible novel anthropometric index was termed angle index (AI).

Central obesity has greater association with type 2 diabetes as compared with total body fat. ${ }^{9}{ }^{10}$ Computed tomography can be used to accurately determine abdominal visceral fat; however, this computation is expensive and time-consuming as compared with less accurate methods. ${ }^{11-13}$ Simpler, inexpensive, less accurate and sometimes debatable 


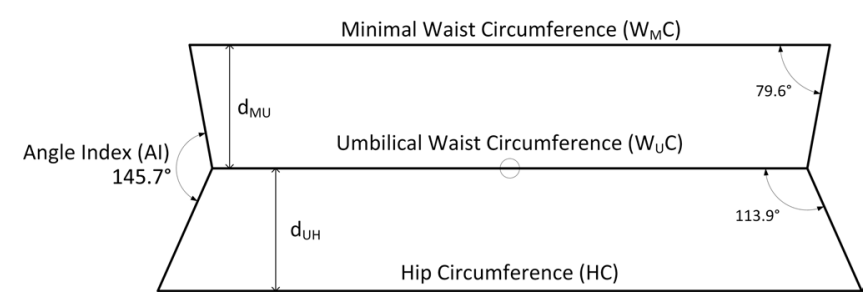

Figure 1 Diagram to conceptualise Al. As an example, $\mathrm{W}_{\mathrm{M}} \mathrm{C}=104.1 \mathrm{~cm} ; \mathrm{W}_{\mathrm{U}} \mathrm{C}=96.8 \mathrm{~cm} ; \mathrm{HC}=114.5 \mathrm{~cm} ; \mathrm{Al}=2.545$ radians or $145.7^{\circ} ; \mathrm{d}_{\mathrm{UH}}=\mathrm{d}_{\mathrm{MU}}=20 \mathrm{~cm}$. $\mathrm{d}_{\mathrm{MU}}$, perpendicular distance from the traverse section of the minimal waist region to the traverse section of the umbilical waist region; $d_{\mathrm{UH}}$, perpendicular distance from the traverse section of the umbilical waist region to the traverse section of the hip region.

alternatives to characterise obesity include body mass index, waist circumference (WC), waist to hip ratio $(\mathrm{W}: \mathrm{H})$, abdominal volume index (AVI) and conicity index (ConI) ${ }^{13-16}$ In this study two forms of WC, W:H, AVI and ConI were obtained. These include minimal waist circumference $\left(\mathrm{W}_{\mathrm{M}} \mathrm{C}\right)$, umbilical waist circumference $\left(\mathrm{W}_{\mathrm{U}} \mathrm{C}\right)$, minimal waist to hip ratio $\left(\mathrm{W}_{\mathrm{M}}: \mathrm{H}\right)$, umbilical waist to hip ratio $\left(\mathrm{W}_{\mathrm{U}}: \mathrm{H}\right)$, abdominal volume index for minimal waist $\left(\mathrm{AVI}_{\mathrm{M}}\right)$, abdominal volume index for umbilical waist $\left(\mathrm{AVI}_{\mathrm{U}}\right)$, conicity index for minimal waist $\left(\operatorname{ConI}_{\mathrm{M}}\right)$ and conicity index for umbilical waist $\left(\operatorname{ConI}_{\mathrm{U}}\right)$. All the aforementioned anthropometric variables and indices, along with AI, were compared in relation to type 2 diabetes.

AI was defined by the following equation with units in radians.

$$
\mathrm{AI}=\pi+\tan ^{-1}\left[\frac{\mathrm{W}_{\mathrm{U}} \mathrm{C}-\mathrm{HC}}{2\left(\mathrm{~d}_{\mathrm{UH}}\right)}\right]-\tan ^{-1}\left[\frac{\mathrm{W}_{\mathrm{M}} \mathrm{C}-\mathrm{W}_{\mathrm{U}} \mathrm{C}}{2\left(\mathrm{~d}_{\mathrm{MU}}\right)}\right]
$$

For further visual simplicity this angle can be converted to degrees. A visual representation of this angle is shown in figure 1 (drawn to scale).

Each circumference is flattened out into a horizontal line which is parallel to the other lines. The dimension, $\mathrm{d}_{\mathrm{MU}}$, can be visualised as the perpendicular distance from the traverse section of the minimal waist region to the traverse section of the umbilical waist region. $d_{\mathrm{UH}}$ can be visualised as the perpendicular distance from the traverse section of the umbilical waist region to the traverse section of the hip region. $\mathrm{d}_{\mathrm{MU}}$ and $\mathrm{d}_{\mathrm{UH}}$ were arbitrarily assigned a value of $20 \mathrm{~cm}$, respectively, since variability of these values was not considered at the onset of the study. The $\mathrm{W}_{\mathrm{M}} \mathrm{C}, \mathrm{W}_{\mathrm{U}} \mathrm{C}$ and $\mathrm{HC}$ data and calculation for AI can be viewed in online supplementary data S1. To the best of our knowledge, an equation of this nature or derivatives of this equation that incorporate $\mathrm{W}_{\mathrm{M}} \mathrm{C}, \mathrm{W}_{\mathrm{U}} \mathrm{C}$ and $\mathrm{HC}$ have not been displayed or demonstrated in the literature.

This study hypothesised that AI was a superior sex independent anthropometric index to discriminate between patients with and without type 2 diabetes as compared with other sex independent indices.

\section{METHODS}

Patients with type 2 diabetes and patients without diabetes, based on medical records, were selected at random from the Eric Williams Medical Sciences Complex and the San Fernando General Hospital in Trinidad and Tobago. Potential participants were contacted and those who volunteered to participate in the study attended examinations specifically for the study. Smokers, pregnant women and alcoholics were excluded from the study. It was strictly ensured that controls had a fasting blood glucose (FBG) $<120 \mathrm{mg}$ / $\mathrm{dL}$ and $\mathrm{HbA} 1 \mathrm{c}<6.5 \%$.

Subjects fasted approximately 8 hours before examination and were instructed to wear light clothing. Initially patients' mass, height and blood pressure readings were obtained on the morning of the blood draw. Patients' $\mathrm{W}_{\mathrm{M}} \mathrm{C}, \mathrm{W}_{\mathrm{U}} \mathrm{C}$ and $\mathrm{HC}$ were measured with a flexible tape, using modified versions of the WHO and the National Health and Nutrition Examination Survey (NHANES) protocol. ${ }^{17} 18$ The $\mathrm{W}_{\mathrm{M}} \mathrm{C}$ tended to the WHO protocol and the $\mathrm{W}_{\mathrm{U}} \mathrm{C}$ tended to the NHANES protocol. For simplification and rapid measurement, $\mathrm{W}_{\mathrm{M}} \mathrm{C}$ was measured at the minimal waist, above the umbilicus, and $\mathrm{W}_{\mathrm{U}} \mathrm{C}$ directly at the umbilical level. Hip circumference was measured as the largest circumference below the umbilicus passing around the gluteus maximus but not extending beyond the gluteal region.

Venous blood samples were drawn and assayed for FBG, HbA1c, total serum triglyceride (Trig), total serum cholesterol (Chol) and high-density lipoprotein (HDL) using an automated chemistry analyser (cobas 6000, Roche Diagnostics, USA). Low-density lipoprotein (LDL) and very low-density lipoprotein (VLDL) were calculated based on Friedewald's estimation. ${ }^{19}$

Both anthropometric and biochemical data published in the study were not used from the hospital medical records. The data published were obtained from study-specific examination of patients.

\section{Statistics}

Software packages $G^{*}$ Power V.3, Minitab V.17 and IBM SPSS V.24 were used for statistical analyses. The $\chi^{2}$ and Fisher's exact test were used to investigate whether there were associations of age, sex and ethnicity categories with type 2 diabetes in table 1 . The $\chi^{2}$ was also used to determine whether the proportions of cases and controls were similar in table 1. The Anderson Darling test was used to determine whether a particular data set was normally distributed. The independent t-test and Mann-Whitney $U$ test were used in table 2 to test for the difference between means and ranks of parameters. The t-test was used for data that were normally distributed, whereas the $\mathrm{U}$ test was used for data that did not follow normal distribution. A general linear model univariate analysis was applied in table 3 to control for age confounder when investigating the difference between the significant sex independent parameters. Adjustment was possibly required since 
Table 1 Comparison of sex, age and ethnicity between subjects with and without type 2 diabetes

\begin{tabular}{|c|c|c|c|c|}
\hline & Total & Non-diabetic patients & $\begin{array}{l}\text { Patients with type } 2 \\
\text { diabetes }\end{array}$ & \\
\hline & n (\%) & n (\%) & n (\%) & $P$ value \\
\hline \multicolumn{5}{|l|}{ Sex } \\
\hline Male & 37 (30.6) & 20 (16.50) & $17(14.0)$ & $0.06^{*}$ \\
\hline $25-40$ & $3(2.5)$ & $1(0.01)$ & $2(0.02)$ & \multirow[t]{4}{*}{$0.01 \dagger$} \\
\hline $41-55$ & 43 (35.5) & 25 (20.7) & $18(14.9)$ & \\
\hline 56-65 & $36(29.8)$ & $10(0.08)$ & $26(21.5)$ & \\
\hline $66-75$ & $36(29.8)$ & $11(0.09)$ & $25(20.7)$ & \\
\hline African & $34(28.1)$ & $15(12.4)$ & $19(15.7)$ & \multirow{2}{*}{$0.35 \dagger$} \\
\hline Mixed & 12 (12.0) & $7(0.06)$ & $5(0.04)$ & \\
\hline
\end{tabular}

${ }^{*} \chi^{2}$ test.

†Fisher's exact test.

there was an association of the age categories with the cases and controls. Receiver operating characteristic (ROC) analysis was used to investigate the performance of a diagnostic test, and the results are displayed in table 4. Spearman's correlation $\left(r_{s}\right)$ was used in table 5 to determine how well the significant sex independent parameters correlated with $\mathrm{HbA1c}$ and FBG levels. Binomial logistic regression was used in table 6 to determine both the crude and adjusted odds of AI cut-off categories in relation to type 2 diabetes.

The limit for type I error was set at $\alpha=0.05$. The effect size (Hedges' g) and power (1- $\beta$ ) chosen were 0.53 and 0.80 , respectively, for sample size calculation, resulting in an estimation of 114 patients required for the study. The effect size chosen was based on differences in means between groups with and without type 2 diabetes for $\mathrm{W}_{\mathrm{M}} \mathrm{C}$ and $\mathrm{W}_{\mathrm{U}} \mathrm{C}$ on preliminary data collected of sample size $\mathrm{n}=44$. The preliminary data set can be accessed in online supplementary data S2. A total of 121 subjects were recruited for the study, which compensated for missing data cells.

\section{Patient and public involvement}

There was no patient or public involvement in the design and conduct of the study. Study participants were given their specific results in the study, which included their age, blood pressure readings, height, mass, $\mathrm{W}_{\mathrm{M}} \mathrm{C}, \mathrm{W}_{\mathrm{U}} \mathrm{C}$, $\mathrm{HC}, \mathrm{W}_{\mathrm{M}}: \mathrm{H}, \mathrm{W}_{\mathrm{U}}: \mathrm{H}, \mathrm{AVI}_{\mathrm{M}}, \mathrm{AVI}_{\mathrm{U}}, \mathrm{ConI}_{\mathrm{M}}, \mathrm{ConI}_{\mathrm{U}}, \mathrm{HbAlc}$ FBG, Trig, Chol, HDL, LDL and VLDL. Any information published from the study would be disseminated to all study participants by the research team.

\section{RESULTS}

Table 1 displays the demographics of patients in the study with statistically equivalent distribution of patients between the groups with and without type 2 diabetes $(p=0.06)$. There was no association of $\operatorname{sex}(p=0.06)$ or ethnicity $(\mathrm{p}=0.35)$ categories in relation to categories with and without type 2 diabetes. There was an association of the age categories to the categories with and without type 2 diabetes $(\mathrm{p}=0.01)$.

Table 2 displays the comparison of parameters between sex and subjects with and without type 2 diabetes, using the t-test or $\mathrm{U}$ test. The sex independent parameters which were significantly higher in patients with type 2 diabetes were systolic blood pressure $(p=0.004), W_{M} \mathrm{C}(p=0.003)$, $\mathrm{W}_{\mathrm{U}} \mathrm{C}(\mathrm{p}<0.001), \mathrm{AVI}_{\mathrm{M}}(\mathrm{p}=0.003), \mathrm{AVI}_{\mathrm{U}}(\mathrm{p}<0.001)$, ConI $_{\mathrm{M}}$ $(p=0.003)$, HbA1c $(p<0.001), \quad$ FBG $(p<0.001)$, Trig $(\mathrm{p}<0.004)$, VLDL $(\mathrm{p}=0.015)$ and AI $(\mathrm{p}<0.001 ; 1-\beta=0.99)$. The effect sizes between subjects with and without diabetes, at the end of the study, for $\mathrm{W}_{\mathrm{M}} \mathrm{C}, \mathrm{W}_{\mathrm{U}} \mathrm{C}$ and $\mathrm{AI}$ were $0.57,0.68$ and 0.76 , respectively.

Table 3 summarises the comparison of adjusted means for significant sex independent parameters between patients with and without type 2 diabetes. The means were adjusted for age since table 1 demonstrates that there was a significant association between the age categories and the categories of with and without type 2 diabetes $(p=0.01)$. ConI $I_{M}$ was the only previous significant sex independent parameter from table 2 that was not significantly different between cases and controls when adjustment was made for age $(\mathrm{p}=0.055)$. 
Open access

Table 2 Comparison of parameters in study between sex, and between patients with and without type 2 diabetes

\begin{tabular}{|c|c|c|c|c|c|c|c|}
\hline Parameter & Total subjects & Male & Female & $P$ value & $\begin{array}{l}\text { Subjects without } \\
\text { type } 2 \text { diabetes }\end{array}$ & $\begin{array}{l}\text { Subjects with type } \\
2 \text { diabetes }\end{array}$ & P value \\
\hline Age (years) & $\begin{array}{l}58.9 \pm 10.5 \\
(n=121)\end{array}$ & $\begin{array}{l}60.2 \pm 9.6 \\
(n=37)\end{array}$ & $\begin{array}{l}58.4 \pm 10.9 \\
(n=84)\end{array}$ & 0.37 & $\begin{array}{l}57.2 \pm 11.4 \\
(n=50)\end{array}$ & $\begin{array}{l}60.2 \pm 9.7 \\
(n=71)\end{array}$ & 0.06 \\
\hline SBP $(\mathrm{mm} \mathrm{Hg})$ & $\begin{array}{l}145.1 \pm 21.3 \\
(n=121)\end{array}$ & $\begin{array}{l}142.0 \pm 17.1 \\
(n=37)\end{array}$ & $\begin{array}{l}146.5 \pm 22.8 \\
(n=84)\end{array}$ & 0.23 & $\begin{array}{l}138.6 \pm 18.0 \\
(n=50)\end{array}$ & $\begin{array}{l}149.7 \pm 22.3 \\
(n=71)\end{array}$ & 0.004 \\
\hline $\mathrm{DBP}(\mathrm{mm} \mathrm{Hg})$ & $\begin{array}{l}87.2 \pm 10.8 \\
(n=121)\end{array}$ & $\begin{array}{l}87.6 \pm 9.5 \\
(n=37)\end{array}$ & $\begin{array}{l}87.1 \pm 11.4 \\
(n=84)\end{array}$ & 0.64 & $\begin{array}{l}86.6 \pm 9.5 \\
(n=50)\end{array}$ & $\begin{array}{l}87.7 \pm 11.7 \\
(n=71)\end{array}$ & 0.56 \\
\hline Height (m) & $\begin{array}{l}1.64 \pm 0.10 \\
(n=121)\end{array}$ & $\begin{array}{l}1.72 \pm 0.08 \\
(n=37)\end{array}$ & $\begin{array}{l}1.61 \pm 0.09 \\
(n=84)\end{array}$ & $<0.001$ & $\begin{array}{l}1.66 \pm 0.10 \\
(n=50)\end{array}$ & $\begin{array}{l}1.63 \pm 0.10 \\
(n=71)\end{array}$ & 0.16 \\
\hline Mass (kg) & $\begin{array}{l}79.4 \pm 21.2 \\
(n=120)\end{array}$ & $\begin{array}{l}85.0 \pm 27.7 \\
(n=37)\end{array}$ & $\begin{array}{l}77.0 \pm 17.3 \\
(n=83)\end{array}$ & 0.08 & $\begin{array}{l}75.1 \pm 12.4 \\
(n=49)\end{array}$ & $\begin{array}{l}82.4 \pm 25.3 \\
(n=71)\end{array}$ & 0.18 \\
\hline BMI $\left(k g / m^{2}\right)$ & $\begin{array}{l}29.4 \pm 7.3 \\
(n=120)\end{array}$ & $\begin{array}{l}28.5 \pm 8.5 \\
(n=37)\end{array}$ & $\begin{array}{l}29.8 \pm 6.7 \\
(n=83)\end{array}$ & 0.04 & $\begin{array}{l}27.3 \pm 4.5 \\
(n=49)\end{array}$ & $\begin{array}{l}30.9 \pm 8.4 \\
(n=71)\end{array}$ & 0.02 \\
\hline $\mathrm{W}_{\mathrm{M}} \mathrm{C}(\mathrm{cm})$ & $\begin{array}{l}94.0 \pm 11.7 \\
(n=121)\end{array}$ & $\begin{array}{l}94.3 \pm 9.4 \\
(n=37)\end{array}$ & $\begin{array}{l}93.8 \pm 12.7 \\
(n=84)\end{array}$ & 0.81 & $\begin{array}{l}90.2 \pm 10.0 \\
(n=50)\end{array}$ & $\begin{array}{l}96.7 \pm 12.2 \\
(n=71)\end{array}$ & 0.003 \\
\hline $\mathrm{W}_{\mathrm{u}} \mathrm{C}(\mathrm{cm})$ & $\begin{array}{l}100.5 \pm 13.3 \\
(n=121)\end{array}$ & $\begin{array}{l}97.9 \pm 10.9 \\
(n=37)\end{array}$ & $\begin{array}{l}101.6 \pm 14.1 \\
(n=84)\end{array}$ & 0.15 & $\begin{array}{l}95.4 \pm 10.1 \\
(n=50)\end{array}$ & $\begin{array}{l}104.0 \pm 14.2 \\
(n=71)\end{array}$ & $<0.001$ \\
\hline $\mathrm{HC}(\mathrm{cm})$ & $\begin{array}{l}106.3 \pm 11.8 \\
(n=121)\end{array}$ & $\begin{array}{l}101.5 \pm 8.3 \\
(n=37)\end{array}$ & $\begin{array}{l}108.4 \pm 12.5 \\
(n=84)\end{array}$ & 0.002 & $\begin{array}{l}104.2 \pm 9.6 \\
(n=50)\end{array}$ & $\begin{array}{l}107.8 \pm 13.0 \\
(n=71)\end{array}$ & 0.14 \\
\hline $\mathrm{W}_{\mathrm{M}}: \mathrm{H}$ & $\begin{array}{l}0.89 \pm 0.07 \\
(n=121)\end{array}$ & $\begin{array}{l}0.93 \pm 0.05 \\
(n=37)\end{array}$ & $\begin{array}{l}0.87 \pm 0.06 \\
(n=84)\end{array}$ & $<0.001$ & $\begin{array}{l}0.87 \pm 0.07 \\
(n=50)\end{array}$ & $\begin{array}{l}0.90 \pm 0.06 \\
(n=71)\end{array}$ & 0.01 \\
\hline$W_{u}: H$ & $\begin{array}{l}0.94 \pm 0.06 \\
(n=121)\end{array}$ & $\begin{array}{l}0.964 \pm 0.057 \\
(n=37)\end{array}$ & $\begin{array}{l}0.936 \pm 0.060 \\
(n=84)\end{array}$ & 0.02 & $\begin{array}{l}0.92 \pm 0.07 \\
(n=50)\end{array}$ & $\begin{array}{l}0.96 \pm 0.05 \\
(n=71)\end{array}$ & $<0.001$ \\
\hline $\mathrm{AVI}_{\mathrm{M}}$ & $\begin{array}{l}18.1 \pm 4.5 \\
(n=121)\end{array}$ & $\begin{array}{l}18.0 \pm 3.7 \\
(n=37)\end{array}$ & $\begin{array}{l}18.1 \pm 4.8 \\
(n=84)\end{array}$ & 0.83 & $\begin{array}{l}16.6 \pm 3.5 \\
(n=50)\end{array}$ & $\begin{array}{l}19.1 \pm 4.8 \\
(n=71)\end{array}$ & 0.003 \\
\hline $\mathrm{AVI}_{\mathrm{u}}$ & $\begin{array}{l}20.6 \pm 5.7 \\
(n=121)\end{array}$ & $\begin{array}{l}19.4 \pm 4.6 \\
(n=37)\end{array}$ & $\begin{array}{l}21.1 \pm 6.1 \\
(n=84)\end{array}$ & 0.14 & $\begin{array}{l}18.5 \pm 4.0 \\
(n=50)\end{array}$ & $\begin{array}{l}22.0 \pm 6.3 \\
(n=71)\end{array}$ & $<0.001$ \\
\hline Conl $_{M}$ & $\begin{array}{l}1.25 \pm 0.10 \\
(n=120)\end{array}$ & $\begin{array}{l}1.25 \pm 0.10 \\
(n=37)\end{array}$ & $\begin{array}{l}1.25 \pm 0.10 \\
(n=83)\end{array}$ & 0.86 & $\begin{array}{l}1.23 \pm 0.08 \\
(n=49)\end{array}$ & $\begin{array}{l}1.26 \pm 0.11 \\
(n=71)\end{array}$ & 0.003 \\
\hline $\operatorname{Conl}_{u}$ & $\begin{array}{l}1.34 \pm 0.12 \\
(n=120)\end{array}$ & $\begin{array}{l}1.30 \pm 0.11 \\
(n=37)\end{array}$ & $\begin{array}{l}1.35 \pm 0.12 \\
(n=83)\end{array}$ & $<0.001$ & $\begin{array}{l}1.30 \pm 0.09 \\
(n=49)\end{array}$ & $\begin{array}{l}1.36 \pm 0.13 \\
(n=71)\end{array}$ & $<0.001$ \\
\hline $\mathrm{Al}\left({ }^{\circ}\right)$ & $\begin{array}{l}180.9 \pm 13.0 \\
(n=121)\end{array}$ & $\begin{array}{l}180.1 \pm 11.3 \\
(n=37)\end{array}$ & $\begin{array}{l}181.3 \pm 13.8 \\
(n=84)\end{array}$ & 0.67 & $\begin{array}{l}175.5 \pm 12.3 \\
(n=50)\end{array}$ & $\begin{array}{l}184.8 \pm 12.3 \\
(n=71)\end{array}$ & $<0.001$ \\
\hline $\begin{array}{l}\mathrm{HbA} 1 \mathrm{c}(\%)(\mathrm{mmol} / \\
\mathrm{mol})\end{array}$ & $\begin{array}{l}6.8 \% \pm 2.0 \% \\
51.2 \pm 21.7 \mathrm{mmol} / \\
\mathrm{mol} \\
(\mathrm{n}=118)\end{array}$ & $\begin{array}{l}6.3 \% \pm 1.3 \% \\
45.4 \pm 14.1 \mathrm{mmol} / \\
\mathrm{mol} \\
(\mathrm{n}=36)\end{array}$ & $\begin{array}{l}7.1 \% \pm 2.2 \% \\
53.8 \pm 23.9 \mathrm{mmol} / \\
\mathrm{mol} \\
(\mathrm{n}=82)\end{array}$ & 0.13 & $\begin{array}{l}5.4 \% \pm 0.6 \% \\
35.3 \pm 6.3 \mathrm{mmol} / \mathrm{mol} \\
(n=50)\end{array}$ & $\begin{array}{l}7.9 \% \pm 2.0 \% \\
62.9 \pm 21.6 \mathrm{mmol} / \\
\mathrm{mol} \\
(\mathrm{n}=68)\end{array}$ & $<0.001$ \\
\hline FBG (mg/dL) & $\begin{array}{l}126.2 \pm 56.3 \\
(n=118)\end{array}$ & $\begin{array}{l}112.5 \pm 34.2 \\
(n=36)\end{array}$ & $\begin{array}{l}132.3 \pm 62.9 \\
(n=82)\end{array}$ & 0.16 & $\begin{array}{l}89.6 \pm 11.3 \\
(n=49)\end{array}$ & $\begin{array}{l}152.2 \pm 61.0 \\
(n=69)\end{array}$ & $<0.001$ \\
\hline Trig (mg/dL) & $\begin{array}{l}157.5 \pm 102.3 \\
(n=121)\end{array}$ & $\begin{array}{l}171.9 \pm 127.8 \\
(n=37)\end{array}$ & $\begin{array}{l}151.1 \pm 89.0 \\
(n=84)\end{array}$ & 0.34 & $\begin{array}{l}129.9 \pm 69.6 \\
(n=50)\end{array}$ & $\begin{array}{l}176.9 \pm 116.8 \\
(n=71)\end{array}$ & 0.004 \\
\hline Chol (mg/dL) & $\begin{array}{l}191.1 \pm 48.1 \\
(n=121)\end{array}$ & $\begin{array}{l}175.6 \pm 41.7 \\
(n=37)\end{array}$ & $\begin{array}{l}197.9 \pm 49.4 \\
(n=84)\end{array}$ & 0.02 & $\begin{array}{l}194.3 \pm 47.6 \\
(n=50)\end{array}$ & $\begin{array}{l}188.8 \pm 48.7 \\
(n=71)\end{array}$ & 0.54 \\
\hline $\mathrm{HDL}$ (mg/dL) & $\begin{array}{l}47.1 \pm 13.0 \\
(n=120)\end{array}$ & $\begin{array}{l}42.2 \pm 10.6 \\
(n=37)\end{array}$ & $\begin{array}{l}49.3 \pm 13.5 \\
(n=83)\end{array}$ & 0.01 & $\begin{array}{l}50.9 \pm 13.4 \\
(n=50)\end{array}$ & $\begin{array}{l}44.3 \pm 12.1 \\
(n=70)\end{array}$ & 0.008 \\
\hline LDL (mg/dL) & $\begin{array}{l}111.7 \pm 43.8 \\
(n=120)\end{array}$ & $\begin{array}{l}96.6 \pm 40.7 \\
(n=37)\end{array}$ & $\begin{array}{l}118.5 \pm 43.7 \\
(n=83)\end{array}$ & 0.01 & $\begin{array}{l}115.5 \pm 43.2 \\
(n=50)\end{array}$ & $\begin{array}{l}109.0 \pm 44.4 \\
(n=70)\end{array}$ & 0.43 \\
\hline VLDL (mg/dL) & $\begin{array}{l}31.8 \pm 20.7 \\
(n=120)\end{array}$ & $\begin{array}{l}36.0 \pm 25.9 \\
(n=37)\end{array}$ & $\begin{array}{l}30.0 \pm 17.8 \\
(n=83)\end{array}$ & 0.14 & $\begin{array}{l}27.2 \pm 15.1 \\
(n=50)\end{array}$ & $\begin{array}{l}35.1 \pm 23.5 \\
(n=70)\end{array}$ & 0.02 \\
\hline
\end{tabular}

Continued 
Table 2 Continued

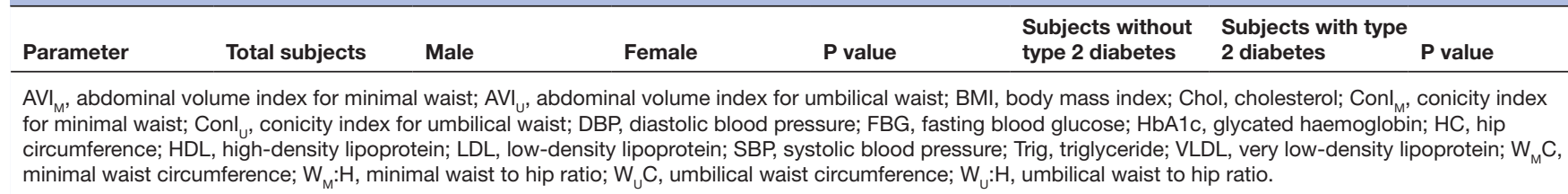

In alignment with the objective of the study, the sex independent parameters that were significantly higher in patients with type 2 diabetes were subjected to ROC analyses. Although both HbA1c and FBG were significant sex independent variables related to type 2 diabetes, they were not included in the ROC analysis since they were already used as exclusion criteria for the controls and would obviously have high area under the curve (AUC). A summary of the AUC is provided in table 4, which reports that the best sex independent discriminator for type 2 diabetes was AI $(\mathrm{AUC}=0.72, \mathrm{p}<0.001)$. Supplementary data of ROC analysis for both sex dependent and independent parameters can be accessed in online supplementary figure 1 and online supplementary data S3 and S4.

The Spearman's correlation provided in table 5 demonstrated that AI had the highest correlation with HbA1c $\left(\mathrm{r}_{\mathrm{s}}=0.28, \mathrm{p}<0.001\right)$ and FBG $\left(\mathrm{r}_{\mathrm{s}}=0.31, \mathrm{p}<0.001\right)$ as compared with the other sex independent parameters.

Binomial logistic regression was applied to cut-off categories of AI relative to the categories of patients with and without type 2 diabetes. The results of the applied binomial logistic regression are highlighted in table 6. One significant result was that patients with type 2 diabetes were four times more likely to have an $\mathrm{AI}>184^{\circ}$ (OR 4.2, $95 \%$ CI 1.8 to 9.9$)$. An AI cut-off of $184^{\circ}$ has lower specificity and higher sensitivity in relation to type 2 diabetes discrimination as compared with $178^{\circ}$, which was graphically represented in the ROC graph of figure 2 . The odds were then adjusted for age, which resulted in AI $>186^{\circ}$ displaying non-significant odds (OR 1.0, 95\% CI 1.0 to 1.1), but all other angles in the table displayed significant odds.

The study was repeated for a total sample size of $n=72$, with equivalent cases and controls. The sample size was calculated based on effect size, $\mathrm{g}=0.72$ for AI and 1$\beta=0.8$, which gave a total of $n=64$. An additional eight samples were taken, which gave the final sample size of 72 for repeat study, since additional assay reagents for HbA1c and FBG were available. There were no additional reagents for Trig, Chol and HDL assays.

In the repeat study, the means of the different parameters were compared between patients with and without type 2 diabetes, adjusted for age, sex and ethnicity. Only HbAlc, FBG, AI, $\mathrm{AVI}_{\mathrm{M}}$ and $\mathrm{AVI}_{\mathrm{U}}$ were significant and independent of sex. The repeat study, in online supplementary data S5, S6, S7 and S8), demonstrated that AI (AUC=0.75, p $<0.001$ ) was the best sex independent anthropometric discriminator for type 2 diabetes.

\section{DISCUSSION}

The study aimed to develop a novel sex independent anthropometric index related to type 2 diabetes which could possibly be used as a predictor for the condition. Application of trigonometry to waist and hip measurements was applied to achieve a novel anthropometric index, termed as angle index (AI). In future clinical practice the angle calculation process could be automated via computing devices. AI is sex independent and more complex in calculation as compared with a singular reading of $\mathrm{W}_{\mathrm{U}} \mathrm{C}$. Apart from AI being significantly different between patients with and without type 2 diabetes, it was demonstrated that patients with type 2 diabetes were four times more likely to have an $\mathrm{AI}>184^{\circ}$ as compared with controls.

According to table 1 there were no associations among the sex and ethnicity categories with cases and control categories; however, there was a significant association between the age categories and categories for with and without type 2 diabetes. This could be expected as patients 45 years and older are at greater risk for type 2 diabetes. ${ }^{20}$ In table 3 , adjustments were made for age when comparing the means of the significant sex independent parameters.

Both FBG and HbAlc values were significantly higher in patients with type 2 diabetes even though some patients with type 2 diabetes were on glucose-lowering medication and had HbAlc values $<6.5 \%$. Sex independent anthropometric indices, $\mathrm{W}_{\mathrm{M}} \mathrm{C}, \mathrm{W}_{\mathrm{U}} \mathrm{C}, \mathrm{AVI}_{\mathrm{M}}, \mathrm{AVI}_{\mathrm{U}}$ and $\mathrm{ConI}_{\mathrm{M}}$, were significantly higher in patients with type 2 diabetes, which is in agreement with a number of studies. ${ }^{89} \mathrm{~W}_{\mathrm{U}} \mathrm{C}$ was the second-best discriminator and one of the simplest and rapid measurements to be taken without further need to perform a calculation. In clinical practice, $\mathrm{W}_{\mathrm{U}} \mathrm{C}$ has been recommended over $\mathrm{W}_{\mathrm{M}} \mathrm{C}$ measurement when considering type 2 diabetes. ${ }^{21}$

In table 3 , the means of parameters independent of sex were compared between patients with and without diabetes with adjustments for age. No adjustments for sex or ethnicity were made since the analysis displayed in table 1 highlighted that there was no association of sex or ethnicity categories with the categories of patients with and without type 2 diabetes. After adjustments for age, AI was still reported to be significantly different between cases and controls.

Based on the ROC analysis and Spearman's correlations performed, as shown in tables 4 and 5 , AI was the best discriminator for type 2 diabetes and had the highest correlation with HbAlc and FBG. This indicates the 


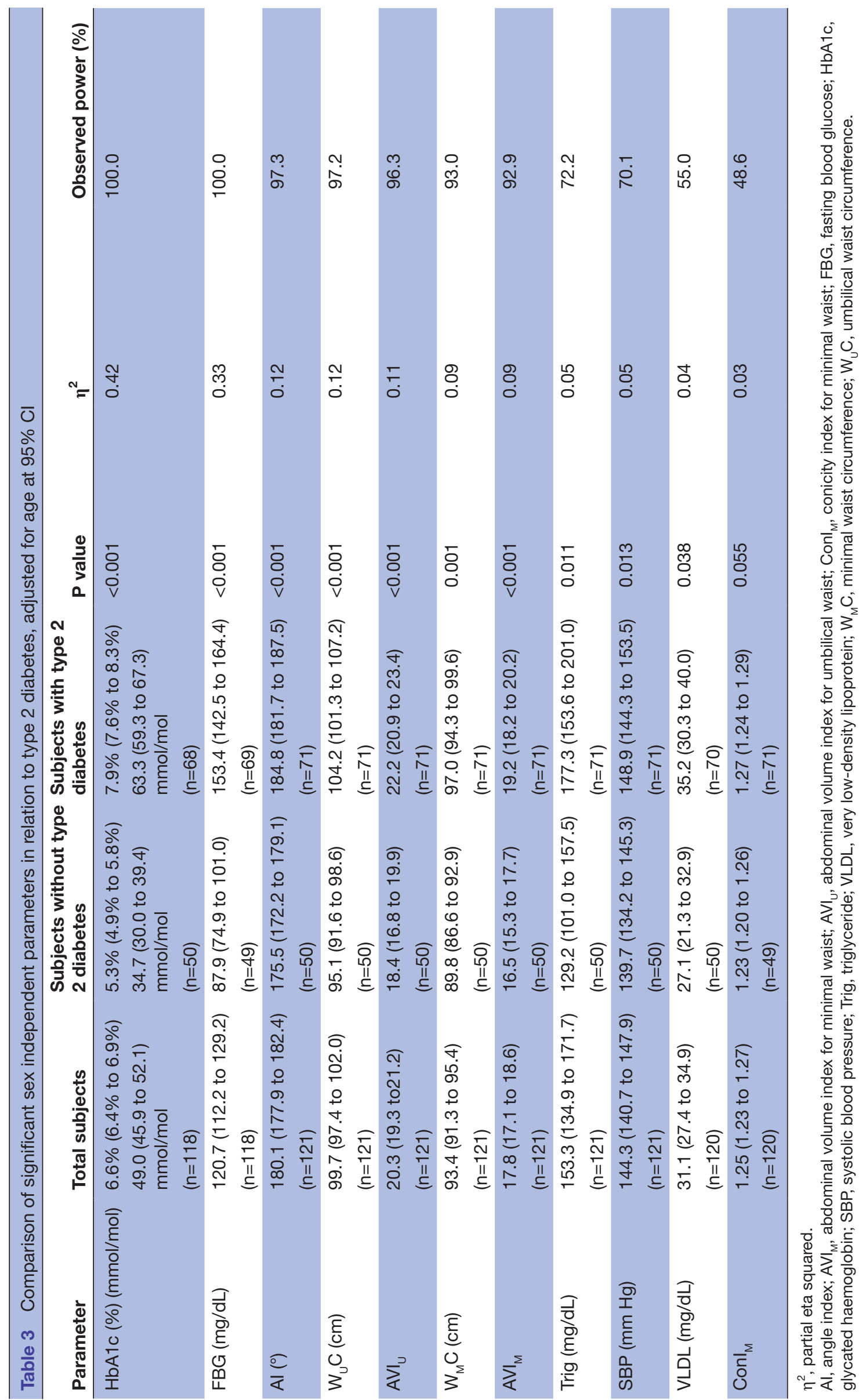


Table 4 ROC analysis of significant sex independent parameters in relation to type 2 diabetes diagnosis

\begin{tabular}{lllll} 
& & & \multicolumn{2}{l}{$\mathbf{9 5 \%} \mathbf{C l}$} \\
\cline { 4 - 5 } Parameter & AUC & P value & Lower bound & Upper bound \\
\hline $\mathrm{Al}$ & 0.72 & $<0.001$ & 0.62 & 0.81 \\
$\mathrm{~W}_{\mathrm{U}} \mathrm{C}$ & 0.70 & $<0.001$ & 0.61 & 0.80 \\
$\mathrm{AVI}_{\mathrm{U}}$ & 0.70 & $<0.001$ & 0.61 & 0.79 \\
$\mathrm{~W}_{\mathrm{M}} \mathrm{C}$ & 0.67 & 0.002 & 0.57 & 0.77 \\
$\mathrm{AVI}_{\mathrm{M}}$ & 0.67 & 0.002 & 0.57 & 0.77 \\
$\mathrm{Conl}_{\mathrm{M}}$ & 0.66 & 0.002 & 0.57 & 0.77 \\
\hline Trig & 0.64 & 0.01 & 0.54 & 0.75 \\
$\mathrm{SBP}$ & 0.64 & 0.01 & 0.54 & 0.74 \\
\hline $\mathrm{VLDL}$ & 0.62 & 0.02 & 0.52 & 0.73 \\
\hline
\end{tabular}

$\mathrm{Al}$, angle index; $\mathrm{AUC}$, area under the curve; $\mathrm{AVI}_{\mathrm{M}}$, abdominal volume index for minimal waist; $\mathrm{AVI}_{\mathrm{U}}$, abdominal volume index for umbilical waist; Conl ${ }_{\mathrm{M}}$, conicity index for minimal waist; ROC, receiver operating characteristic; SBP, systolic blood pressure; Trig, triglyceride; VLDL, very low-density lipoprotein; $W_{M} C$, minimal waist circumference; $W_{U} C$, umbilical waist circumference.

superiority of AI to the other sex dependent anthropometric variables in relation to type 2 diabetes; however, since AI is reportedly novel, repeat studies are required to qualify its importance or even failure as an obesity characterising index. A single repeat study conducted with $>80 \%$ power and equal number of cases and controls demonstrated that AI appears to be a good sex independent discriminator when compared with other sex independent anthropometric indices.

When considering an AI cut-off category in relation to type 2 diabetes from table 6 as well as the ROC curve in figure 2 , an $\mathrm{AI}$ of $184^{\circ}$ appears to be a good discriminator between patients with and without type 2 diabetes, whereby patients with an angle of $>184^{\circ}$ are more likely to have the condition of type 2 diabetes. This could indicate that once an individual does not exceed an AI of $184^{\circ}$, they could possibly decrease the risk of type 2 diabetes;

Table 5 Spearman's correlation $\left(r_{s}\right)$ of sex independent parameters with $\mathrm{HbA} 1 \mathrm{c}$ and $\mathrm{FBG}$

\begin{tabular}{lll}
\hline Parameter $(\mathbf{n})$ & HbA1c $\mathbf{r}_{\mathbf{s}}$ (p value) & FBG $\mathbf{r}_{\mathbf{s}}$ (p value) \\
\hline $\mathrm{Al}\left({ }^{\circ}\right)(\mathrm{n}=118)$ & $0.28(0.003)$ & $0.31(0.001)$ \\
$\mathrm{W}_{\mathrm{U}} \mathrm{C}(\mathrm{n}=118)$ & $0.25(0.01)$ & $0.26(0.004)$ \\
$\mathrm{AVI}_{\mathrm{U}}(\mathrm{n}=118)$ & $0.25(0.01)$ & $0.26(0.01)$ \\
$\mathrm{W}_{M} \mathrm{C}(\mathrm{n}=118)$ & $0.24(0.01)$ & $0.23(0.01)$ \\
$\mathrm{AVI}_{M}(\mathrm{n}=118)$ & $0.23(0.01)$ & $0.22(0.02)$ \\
$\mathrm{ConI}_{M}(\mathrm{n}=117)$ & $0.26(0.01)$ & $0.20(0.03)$ \\
Trig $(\mathrm{n}=118)$ & $0.17(0.06)$ & $0.25(0.25)$ \\
SBP $(\mathrm{n}=118)$ & $0.10(0.30)$ & $0.13(0.18)$ \\
$\operatorname{VLDL}(\mathrm{n}=117)$ & $0.15(0.11)$ & $0.20(0.03)$ \\
\hline
\end{tabular}

$\mathrm{Al}$, angle index; $\mathrm{AVI}_{\mathrm{M}}$, abdominal volume index for minimal waist; $\mathrm{AVI}_{\mathrm{U}}$, abdominal volume index for umbilical waist; ConI $\mathrm{M}_{\mathrm{M}}$, conicity index for minimal waist; FBG, fasting blood glucose; HbA1c, glycated haemoglobin; SBP, systolic blood pressure; Trig, triglyceride; VLDL, very low-density lipoprotein; $\mathrm{W}_{\mathrm{M}} \mathrm{C}$, minimal waist circumference; $\mathrm{W}_{\mathrm{U}} \mathrm{C}$, umbilical waist circumference. however, this may be a far-reaching conclusion since the study is of a case-control design and only repeated once.

Accurately quantifying central obesity with current anthropometric variables outlined in this study is challenging; however, the development of AI or a geometrical approach to the abdominopelvic region may be a solution to this problem. ${ }^{822} 23$ Further studies are required to compare AI with CT assessment of abdominal fat content. ${ }^{24}$ Once a high correlation of AI can be found with abdominal fat, this may provide evidence that AI can be used as an obesity measure. ${ }^{13}$ Increases in abdominal fat can cause an influx of macrophages into subcutaneous adipose tissue and enlargement of subcutaneous abdominal adipocyte size. Both macrophage influx and adipocyte hypertrophy result in greater secretion of multiple adipokines, which possibly exacerbate insulin resistance resulting in type 2 diabetes. ${ }^{25}{ }^{26}$ The exact interplay of adipokines and the mechanism of action resulting in insulin resistance remains unknown.

Table 6 The odds of patients having type 2 diabetes when considering specific angle index (Al) cut-off values

\begin{tabular}{|c|c|c|}
\hline $\begin{array}{l}\text { Al cut-off } \\
\text { categories }\left(^{\circ}\right) \\
(n=121)\end{array}$ & $\begin{array}{l}\text { Crude odds } \\
(95 \% \mathrm{Cl})\end{array}$ & $\begin{array}{l}\text { Adjusted odds* } \\
\text { (95\% Cl) }\end{array}$ \\
\hline$>178$ & $\begin{array}{l}3.3 \text { ( } 1.5 \text { to } \\
7.0), p=0.002\end{array}$ & $\begin{array}{l}3.1(1.4 \text { to } \\
6.6), p=0.004\end{array}$ \\
\hline$>180$ & $\begin{array}{l}2.8(1.3 \text { to } \\
6.0), p=0.007\end{array}$ & $\begin{array}{l}2.6(1.2 \text { to } \\
5.6), p=0.015\end{array}$ \\
\hline$>182$ & $\begin{array}{l}3(1.4 \text { to } \\
6.4), p=0.006\end{array}$ & $\begin{array}{l}2.7 \text { ( } 1.2 \text { to } \\
6.0), p=0.014\end{array}$ \\
\hline$>184$ & $\begin{array}{l}4.2(1.8 \text { to } \\
9.9), p=0.001\end{array}$ & $\begin{array}{l}3.9(1.6 \text { to } \\
9.4), p=0.002\end{array}$ \\
\hline$>186$ & $\begin{array}{l}3.5 \text { ( } 1.4 \text { to } \\
9.0), p=0.008\end{array}$ & $\begin{array}{l}1.0 \text { ( } 1.0 \text { to } \\
1.1), p=0.308\end{array}$ \\
\hline
\end{tabular}

*Odds of patients having type 2 diabetes, adjusted for age. 


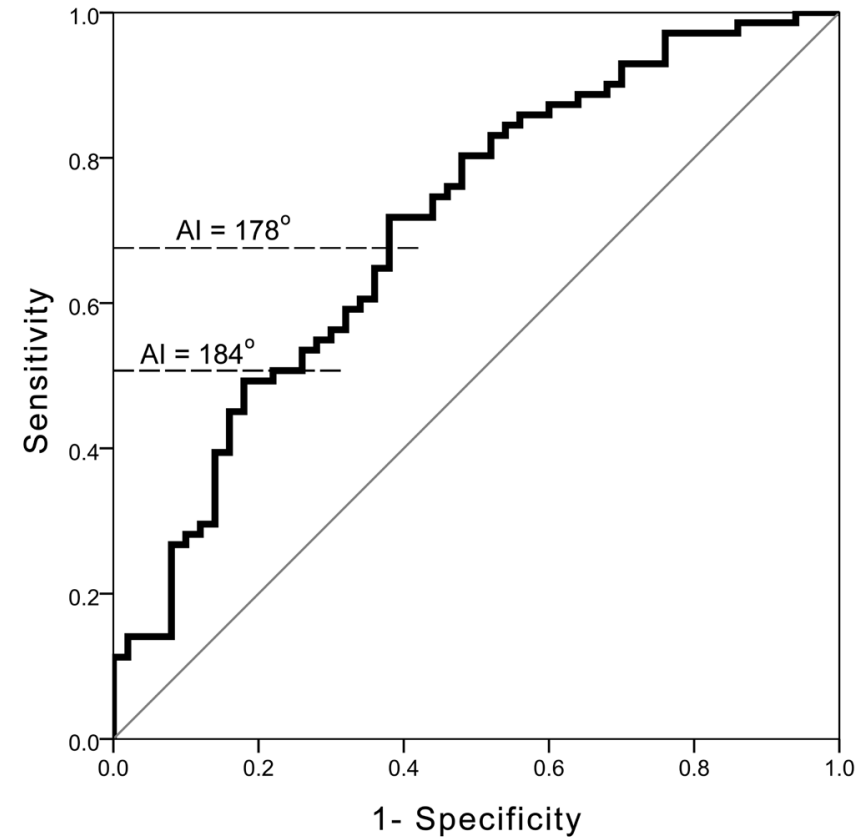

Figure 2 Receiver operating characteristic analysis of angle index ( $\mathrm{Al})$ as test variable in relation to type 2 diabetes diagnosis as state variable.

In retrospect, it was conceptualised that instead of arbitrarily assigning a value to the sum of $\mathrm{d}_{\mathrm{MU}}$ and $\mathrm{d}_{\mathrm{UH}}$, these distances could be measured. In a routine clinical setting $\mathrm{d}_{\mathrm{MU}}$ could be modified by measuring the distance from the minimal waist to the umbilical waist along the posterior body trunk. Likewise, a similar measurement approach could be done for $\mathrm{d}_{\mathrm{UH}}$ from the umbilical waist to the hip along the posterior body trunk. This study does not provide data or analysis for modified measurements of $\mathrm{d}_{\mathrm{MU}}$ and $\mathrm{d}_{\mathrm{UH}}$, but it may be worthwhile to determine if such could alter AI sufficiently to have greater association with type 2 diabetes.

It is strongly recommended that WC should be part of a patient's medical history, even if standardised WHO and NHANES protocols are not followed. Obesity characterisation is important for patient care and disease risk assessment. Further development of AI or geometrical approaches to the abdominopelvic region may have the potential to serve as a valuable predictor for type 2 diabetes. Additionally, it may be worthwhile to extend the concept of AI to cardiovascular disease, metabolic syndrome, perioperative risk and human attractiveness.

\section{Strengths and limitations}

The study was sufficiently powered $(>80 \%)$ when considering the difference between the AI of patients with and without type 2 diabetes. The computation of AI is more complex as compared with calculation of other anthropometric indices, which may limit the use of AI. The design of the study was not prospective and thereby cannot conclusively demonstrate that AI would be the best predictor for type 2 diabetes or pre-diabetes.
CONCLUSION

The development of a novel sex independent anthropometric index, termed as angle index (AI), was accomplished. AI in its initial stage of development appears to be a relevant discriminator for type 2 diabetes when compared with other sex independent anthropometric indices. Repeat studies in different populations are required to fully assess AI as an obesity measure; however, the geometrical approach to the abdominopelvic region may have future relevance in metabolic diagnostics.

Acknowledgements The authors would like to thank The University of the West Indies (St Augustine), the Eric Williams Medical Sciences Complex and the San Fernando General Hospital of Trinidad and Tobago for assistance. The authors would also like to thank Miss Samantha Raman for conducting the repeat study and analysis.

Contributors TGR conceptualised the study; interviewed the study participants; analysed blood samples and data; wrote and edited the initial and final versions of the manuscript. SN sourced funding for the study; recruited assistance for the study; supervised and managed the study; edited the final versions of the manuscript. Both authors were responsible for the final version of the published article.

Funding This work was supported by The University of the West Indies, St Augustine Campus (grant number CRP.3.NOV17.4).

Competing interests None declared.

Patient consent Obtained.

Ethics approval Ethical approval was obtained from the Campus Research Ethics Committee, The University of the West Indies, St Augustine, and was conducted according to the principles expressed in the Declaration of Helsinki. The study was explained in full detail to each subject by one of the authors prior to written consent in the presence of a second witness.

Provenance and peer review Not commissioned; externally peer reviewed.

Data sharing statement The data for this study were included in the manuscript. Supplementary data and analysis can be accessed from the Mendeley repository (DOI 10.17632/dtxy4j6pcn.1). All data have been provided in the study and anyone is permitted to use the data provided that the article is properly cited.

Open access This is an open access article distributed in accordance with the Creative Commons Attribution Non Commercial (CC BY-NC 4.0) license, which permits others to distribute, remix, adapt, build upon this work non-commercially, and license their derivative works on different terms, provided the original work is properly cited, appropriate credit is given, any changes made indicated, and the use is non-commercial. See: http://creativecommons.org/licenses/by-nc/4.0/.

\section{REFERENCES}

1. Meigs JB. Multiple biomarker prediction of type 2 diabetes. Diabetes Care 2009;32:1346-8.

2. Abbasi A, Peelen LM, Corpeleijn E, et al. Prediction models for risk of developing type 2 diabetes: systematic literature search and independent external validation study. BMJ 2012;345:e5900.

3. Mannarino M, Tonelli M, Allan GM. Tools for Practice Screening and diagnosis of type 2 diabetes with $\mathrm{HbA} 1 \mathrm{c}$. Can Fam Physician 2013;59:2013.

4. Henss R. Waist-to-hip ratio and female attractiveness. Evidence from photographic stimuli and methodological considerations. Pers Individ Dif 2000;28:501-13.

5. Singh D, Dixson BJ, Jessop TS, et al. Cross-cultural consensus for waist-hip ratio and women's attractiveness. Evol Hum Behav 2010;31:176-81.

6. Platek SM, Singh D. Optimal waist-to-hip ratios in women activate neural reward centers in men. PLoS One 2010;5:1-5.

7. Dixson BJ, Grimshaw GM, Linklater WL, et al. Eye-tracking of men's preferences for waist-to-hip ratio and breast size of women. Arch Sex Behav 2011;40:43-50.

8. Guerrero-Romero F, Rodríguez-Morán M. Abdominal volume index. An anthropometry-based index for estimation of obesity is strongly related to impaired glucose tolerance and type 2 diabetes mellitus. Arch Med Res 2003;34:428-32. 
9. Vazquez G, Duval S, Jacobs DR, et al. Comparison of body mass index, waist circumference, and waist/hip ratio in predicting incident diabetes: a meta-analysis. Epidemiol Rev 2007;29:115-28.

10. Ashwell M, Gunn P, Gibson S. Waist-to-height ratio is a better screening tool than waist circumference and BMI for adult cardiometabolic risk factors: systematic review and meta-analysis. Obes Rev 2012;13:275-86.

11. Maurovich-Horvat P, Massaro J, Fox CS, et al. Comparison of anthropometric, area- and volume-based assessment of abdominal subcutaneous and visceral adipose tissue volumes using multidetector computed tomography. Int J Obes 2007;31:500-6.

12. Snijder MB, Visser M, Dekker JM, et al. The prediction of visceral fat by dual-energy X-ray absorptiometry in the elderly: a comparison with computed tomography and anthropometry. Int $J$ Obes Relat Metab Disord 2002;26:984-93.

13. Gurunathan U, Myles PS. Limitations of body mass index as an obesity measure of perioperative risk. $\mathrm{Br} J$ Anaesth 2016;116:319-21.

14. Flora MS, Mascie-Taylor CGN, Rahman M. Conicity index of adult bangladeshi population and their socio-demographic characteristics. Ibrahim Med Coll J 2009;3:1-8.

15. Tonding SF, Silva FM, Antonio JP, et al. Adiposity markers and risk of coronary heart disease in patients with type 2 diabetes mellitus. Nutr J 2014;13:124.

16. Motamed N, Perumal D, Zamani F, et al. Conicity index and waist-to-hip ratio are superior obesity indices in predicting 10year cardiovascular risk among men and women. Clin Cardiol 2015;38:527-34.

17. World Health Organization. Waist Circumference and Waist-Hip Ratio: Report of a WHO Expert Consultation. Geneva, Switzerland, 2008
18. Centres for Disease Control and Prevention. Anthropometry procedures manual. $2007 \mathrm{http}: / / w w w . c d c . g o v / \mathrm{nchs} /$ data/nhanes/ nhanes_07_08/manual_an.pdf

19. Friedewald WT, Levy RI, Fredrickson DS. Estimation of the concentration of low-density lipoprotein cholesterol in plasma, without use of the preparative ultracentrifuge. Clin Chem 1972;18:499-502.

20. Alva ML, Hoerger TJ, Zhang P, et al. Identifying risk for type 2 diabetes in different age cohorts: does one size fit all? BMJ Open Diabetes Res Care 2017;5:e000447.

21. Mendes R, Almeida A, Almeida JP, et al. International Conference on November 02-04, 2015. In: Anthropometric assessment of obesity in patients with type 2 diabetes in clinical practice: midpoint waist circumference vs. umbilical waist circumference. Atlanta, USA 2015.

22. Qiao Q, Nyamdorj R. Is the association of type II diabetes with waist circumference or waist-to-hip ratio stronger than that with body mass index? Eur J Clin Nutr 2010;64:30-4.

23. Bosy-Westphal A, Booke CA, Blöcker T, et al. Measurement site for waist circumference affects its accuracy as an index of viscera and abdominal subcutaneous fat in a Caucasian population. $J$ Nutr 2010;140:954-61.

24. Yoshizumi T, Nakamura T, Yamane M, et al. Abdominal fat: standardized technique for measurement at CT. Radiology 1999;211:283-6.

25. Surmi BK, Hasty AH. Macrophage infiltration into adipose tissue: initiation, propagation and remodeling. Future Lipidol 2008;3:545-56.

26. Papaetis GS, Papakyriakou P, Panagiotou TN. State of the art paper Central obesity, type 2 diabetes and insulin: exploring a pathway full of thorns. Arch Med Sci 2015;3:463-82. 